\title{
The Historical and Legal Development of Nonprofit Sector in Albania: Case Study - Red Cross Albania
}

\author{
Alkida Hasaj, PhD \\ Lecturer, University of Shkodra "Luigj Gurakuqi”, Faculty of Economy, Department of Tourism, Shkoder \\ Albania, Sheshi "2 Prilli", Shkoder, Albania; Email: alkidahasaj@yahoo.com \\ Ervis Krymbi, PhD
}

Lecturer, University of Shkodra "Luigj Gurakuqi", Faculty of Social Science, Department of Geography Shkoder, Albania, Sheshi "2 Prilli", Shkoder, Albania; Email: elvis.skadar@gmail.com

\section{Doi:10.5901/ajis.2015.v4n3s1p90}

\section{Abstract}

\begin{abstract}
Regardless developed or in developing countries, the world has experienced a sudden expansion of the Nonprofit sector in recent decades. This happen because the Nonprofit sector is very important for the whole scheme of a country life and the rapid changes in environmental conditions. But the Philanthropic activities has been developed since in the ancient times. The first traces of philanthropy among Albanians have early roots and lie since the period of the Middle Ages. Philanthropy in Albania is strongly connected to social, economic and historical development of the country. The purpose of this study is to show the historical and legal development of nonprofit sector in Albania. The reason for historical treatment in this paper, is conducted in order to see the beginnings and development until our day of philanthropic activities of non-profit organizations in Albania. It is explored also the legal aspect of nonprofit sector in Albania. The data to conduct this paper were collected from the contemporary literature in this field. Also are provided from primary data, using qualitative research through in-depth interviews with managers of nonprofit organization "Red Cross Albania". The findings of this study show that: The creation and development process of non-profit organizations in Albania, dates back to the beginning of democracy and economic openness. Still it needs further improvement of the legal environment for NPOs in Albania.
\end{abstract}

Keywords: Non-Profit Organizations, Historical Development, Legal Aspects, Red Cross.

\section{Introduction}

The non-profit sector is very important for the whole scheme of a country life. Civil society and various organizations within it play an important role in the economic, social and political developments of a country, by building public consensus, encouraging public participation in the formulation and implementation of public reforms, providing a wide range of services, improving transparency and accountability in the public sector (Agaraj, Pjero, Guga 2012).

The nonprofit sector is currently experiencing a period of significant changes. In the global level, during the last 30 years had a huge increase in the number of non-profit organizations and this in response to changes in environmental, social and economic conditions (Hasaj dhe Kruja, 2012:33). These conditions include the impact of climate change, growth on national debt, emergencies from new disease, destruction of some traditional political structures and continuing of armed conflicts. Nearly all contemporary charity organizations regardless of whether they are university, zoo or social services, are experiencing these economic, social and economic pressure. How these and other serious issues are recognized and treated, are crucial for success and survival of the organization (Stubbs, 1998: 17). Dozens of non-profit organizations also operate in Albania. As a result there is a growth in competition among organizations that operate in this sector.

The Philanthropic activities has been developed since in the ancient times. The first traces of philanthropy among Albanians have early roots and lie since the period of the Middle Ages. Philanthropy in Albania is strongly connected to social, economic and historical development of the country.

The purpose of this study is to show the historical and legal development of nonprofit sector in Albania. Given the aim of this paper, it is important to start with defining the term nonprofit organization. Nonprofit organization can be defined as an institution that exist for ensuring general wellness of society, through the collection of appropriate resources or serving physical goods and services. Such organizations do not exist to ensure personal interest or to distribute 
benefits to stakeholders or members. They can however to hire staff or to participate in activity designed in providing income in assisting them in fulfillment of their mission (Sergante, 2009). Over the years, many authors have developed different terminology for the same concept as the third sector, independent sector, nonprofit sector, charitable sector and the voluntary sector. The third sector is different from government and the private sector. The third sector is an area where neither the government or the private sector has no the desire to engage, so that the third sector has an important role to play. Third Sector consists of individuals and groups that come together to achieve voluntary activities (Sergant, 2009: 4).

Salamon, Sokolowski and List (2003) expressed the difference in the size of the nonprofit sector in different countries. Following the suggestions of Weisbrod, (1978) they proposed that nonprofit sector size is determined by the market and government failure. Authors predict that nonprofit sector size will vary depending on:

a) Heterogeneity of the population: As different are the ethnicities and religions, more debates will be about what a government can do and so the greater will be the role of nonprofit organizations.

b) Size of government: As much as a government do, the less the need for the nonprofit sector.

c) The size of funding for nonprofit organizations that come from charitable donations.

\section{The Historic Development of Philanthropic Activities in Albania}

The Philanthropic activities has been developed since in the ancient times. The reason for historical treatment on this paper is conducted in order to see the beginnings and development until our day of philanthropic activities and non-profit organizations in Albania.

Philanthropy in Albania is strongly connected to social, economic and historical development of the country. The first traces of philanthropy among Albanians have early roots and lie since the period of the Middle Ages. The word philanthropy is derived from ancient Greek and if it is translated in Albanian, it means love of humanity. So it goes beyond the bounds of charity, philanthropy extends to a much broader plane, with a much larger mission and have a more noble sense. Within the framework of philanthropy, "dear" is not relative, but all mankind. As an activity that includes all mankind regardless of tribal, religious, racial and any other difference. So philanthropy is also an ideal, a goal that requires improvement of human society (Hoxha, 2011).

The history of development of NPO (Non-Profit Organization) in Albania is divided in three periods. The first period conclude with the end of Second World War, the second phase covered the period of the communist regime during the years 1945 to 1990, meanwhile the third period include that after the year 1990 up to our days.

Albania has been under the domination of Ottoman Empire until the announcement of Independency in 1912. During the first period, the philanthropic activity was conducted at a time when the country was under the administration of the Ottoman Empire. During the years 1870 and 1890, Albania had about 80 organizations, most of which operate as humanitarian organizations sustained from different religious communities (Agaraj, Pjero and Guga, 2012).

In 1912, Albania won the independency, but the proper state began with the Lushnja Congress and with the government created by this congress. The period between 1912-1920 has been an uncertain time. At the beginning of this period the philanthropic activities were performed by Albanians expatriate, in the subsequent period, despite the involvement of the diaspora, its commitment began to wane. On the first decade of the twentieth century, were about 130 associations and organizations, as well as several foundations, religious institutions and other institutions of "civil society". These organizations had political, religious, cultural or nationalist orientation. Some of them were created in diaspora, especially in the US, UK, France, Austria, Romania and Italy (USAID, 2002).

The independency of Albanian did not lead to an expansion of charitable and philanthropic activity. At the moment the Albanians had his own state, spread the opinion that the job previously handled by Albanian expatriate, but also those living in the country, now belonged to the state. In Albania at that time, the state was seen as the parent of society and not as a regulator of relationship and guarantor of law in the country. Charitable and philanthropic activities often has had at the center of its support the development, modernization and emancipation of the Albanian people. Education has been the main object of philanthropic and charitable activities developed among Albanians (Hoxha, 2011).

During the reign of King Zog to Albania appeared dim donations for the development of education, and other activities. Ministry of Interior, in a report to the Prime Minister in 1936 on homelessness and begging phenomenon, insist on immediate action from the state because there is a lack of charitable institutions in Albanian society (AQSH, 1936). Even in the late 30s, when they were created Albanian Red Cross, donations for the activities of this organization were too small. Thus in 1937 the income of the Red Cross were 273 thousand gold francs, of which 3.800 were aid that came from within Albania and 12.000 were aid coming from abroad. The climate created by the legislation transformed the 
government in the main destination of donations for philanthropic purposes. The state will thus become the leader and main organizer of the event, often not so directly, but through its subordinate institutions such as Albanian Red Cross.

During the years 1939-1945, the years of World War II in Albania, as in most of countries in Europe, was accompanied by social, political and economic acute problems. The presence of foreign armies in Albanian area, antifascist resistance and ongoing clashes between various political factions, will greatly hinder the situation in the country. Red Cross diverted and placed under the control of fascist institutions. His direction was undertaken by Maja Jacomoni, the wife of Italian King representatives in Albania, Francesco Jacomoni (Hoxha, 2011).

Setting up of communist regime after World War II, which quickly became one of the most brutal dictatorships in Europe, completely destroyed the hopes for an active civil society, or even academic discussions on this concept, for almost half a century in the country. Social organizations, associations, intellectual groups, representatives of different social layers were allowed to carry on their activity under the strict control of government. This process of centralization was more strong in Albania than in the all other countries of Eastern Europe. The regime had its peak in 1967 when it were closed all religious objects (Agaraj, Pjero and Guga, 2012: 15).

During the past two decades since the fall of the dictatorship, the Albanian civil society has made great strides forward, reaching today's a moderated development. While the public debate about the role of civil society has intensified in recent years, there have been only a few studies, which have provided a fragmented knowledge (IDN and CIVICUS, 2010). There are four stages to development of third sector: the transition period (1991-1996), crisis period (1997-2001); period after crisis and maturity of NGO-s (2002-2005) and a collapse period after 2005 (Agaraj, Pjero and Guga, 2012: 15).

Despite the weakness of the third sector in Albania, positive efforts have been made recently by the Albanian government to improve legislation on civil society. On 7 May 2001 the Albanian Parliament approved two very important laws for the further development of civil society. These are law no. 8788, "On Non-Profit" and law no. 8789, "On the Registration of Non-Profit". In a summarized way these two laws regulate five aspects of the operation of non-profit organizations, namely: the establishment, registration, operation, organization, activity. In October 2007, the Ministers Council decided to establish a special budget of the State Budget "Supporting civil society". In March 2009, the Albanian Parliament approved the law "On the organization and functioning of civil society support agency" and procedures applicable to the distribution of funds to support civil society. Other steps were undertaken by international organizations towards strengthening civil society in Albania. One of the most important results of these initiatives is broad consultation and approval of the Charter of Civil Society in 2009 (IDN and CIVICUS, 2010).

\section{Legal Environment of Non-Profit Organizations in Albania}

Cooperation with government at any level is considered normal and necessary by NPOs. They recognize the role of the state in their activities and see the state as an important partner because of its facilitator role. However, the opportunities for sustainable cooperation NPOs - State are not considered strong. Methods of cooperation with the state are similar to the collaborations with other NPOs including: exchange of information's, experiences and joint projects. Some NPOs are regularly invited in meetings to assist the State in various issues. As collaborations NPO - NPO, sometimes cooperation NPO - State is a requirement for some type of funding by donors. In most examples of collaborations NPOs - State, the state is in the position of the donor. Financial support provided by the state is in various ways. Sometimes state directly funds some of the activities or projects and sometimes assist by providing free use of offices, conference rooms, vehicles, etc. Some NPOs have been contracted by the state to train their staff for strategy development, project implementation, etc (Partners Albania, 2002).

The legal environment in Albania in which NPOs operate did not change significantly in 2014. No tangible progress has been achieved with regard to registration procedures, the taxation system, or the operational environment. In addition, the government failed to take action on the draft Law on Volunteerism for the fourth consecutive year (USAID, 2014). In Albania, all NPO-s that are located outside the capital go in Tirana to conduct the registration process to Tirana Court of First Instance and subsequently registered in the local tax authorities. NPOs are possible to compete for grants only after registration in tax authorities. According to the Law, the registered NPOs are obliged to submit annual balance to the tax authorities. So far, there is still no official number of NPO-s published by the District Court of Tirana. It is a fact the number of organizations active in the country, is much lower than the number of registered organizations. In its report on assessment of Albania needs, conducted by TACSO (Technical Assistance for Civil Society Organizations) and published in 2011, the number of officially registered organizations were 2231. Meanwhile, the General Directorate for Prevention of Money Laundering (DPPPP) has published on its website the list of organizations registered in the tax 
authorities in the Republic of Albania by June 2010 and this number is 1651 non-profit organizations (Partners Albania, 2013).

Civil Society is the subject of control and inspection by the tax authorities and other authorities state, as the labor inspectorate. The tax authorities may impose penalties for civil society that have failed for fulfill the tax procedures and financial management, as delivery on annual balance dispatch and other periodic reports (USAID, 2013). Tax Incentives, do not sufficiently motivate the private sector to sustain activities of NPOs. In addition, the regulatory framework for sub contracting of NPOs by central or local government remains incomplete. Specialized legal services for NPOs can be found in the capital and less in other large cities (USAID, 2011).

On December 29, 2014, the Council of Ministers approved a decision to implement provisions of the Law on Tax on Value Added in the Republic of Albania, which was passed in 2014. The decision clarifies several ambiguities with regard to economic activity and financial control of NPOs. First, it now recognizes that funds, grants, and membership fees are tax-exempt for non-profit organizations. Second, economic activities may not exceed 20 percent of non-profit organizations' annual revenues. Third, the amendments reinforce the government's obligation to reimburse VAT that is accrued as part of activity supported through agreements with the government. Finally, the amendments introduce rules clarifying the application of VAT on fundraising activities (USAID, 2014).

The creation and development process of non-profit organization in Albania, dates back to the beginning of democracy and economic openness. This has happend due the assistance provided by international organizations like the World Bank, Sorors Foundation Society, Development Program of United Nations, and the European Union, etc. In the absence of foreign donors, it would be a limited number of non-profit organizations in Albania, because these donors are the majority of which support them financially (Picari, 2009). However is created a dependency to international donors, as a result of lack of financial support from central and local government for services provided by NPOs (USAID, 2006). For this reason NPOs to survive financially, are obliged to follow the desires and projects prepared by donors (Mai, 1999). But, regardless of this dependency, on funds or donations from foreign donors, they can undertake their economic activities. Nonprofit organizations in Albania may already performing both the economic activity, and this constitutes a most important changes on new legislation. Thus non-profit organizations to achieve the purpose and operation predicted in the statute, they have the right to perform economic activity, like any other subject of the civil right (Law 8788 for Nonprofit Organizations Article 36/1). With economic activities would mean any business activities which are performed permanently or regularly.

Foreign organizations and institutions have seen appropriate to canalize their funds through the Albanian government, to better management and develop the concept of sustainability of civil society. In other words, finally it became expedient that if the funds will be managed by a common agent which controls the mechanisms of decisionmaking, implementation and control of implementation, the donated funds will be used well and the results will be satisfactory for donor headquarters. This action in the foreground sounds reasonable, given that aims to avoid the repetition of projects by different actors. But based on the current functioning of the Albanian administration, this strategy has its difficulties to implement, not to mention the fact that it gives the government a great power in the distribution of funds to civil society and reflects the risk of monopolization of these funds by organizations and associations that satisfy the government and its interests, against those who criticize or make that pressure (Picari, 2009).

Recognition and proper implementation of legislation by the NPOs is a responsibility and necessity, as for all other entities operating in the Albania. The legislation is one of the landmarks on the basis of which is conducted the assessment of non-profit organizations activities, but on the other hand, the law provides administrative or judicial opposition to the possible actions of NPOs, not in accordance with it, which may violate the rights of entities that interact with them. The Law on Non-Profit Organizations enacted in 2001 requires a NPOs to adopt a charter that defines its internal management rules, scope of activities, financial reporting, and procedures for its establishment and dissolution. Based on a request from the competent state body, a court can order the dissolution of a nonprofit organization if the organization engages in activities that are illegal or in conflict with the Constitution of Albania; was not established according to the requirements of the law; or has become insolvent. NPOs did not report any cases of administrative impediments or state harassment during 2014 (USAID, 2014).

On September 18, 2014, the government of Albania approved the Law on the "Right to Inform". The law introduces new definitions on what information can be classified as secret, modalities to provide partial information when complete information cannot be provided, and time limits and feedback systems. The law also promotes the use of information and communications technology (ICT) to improve transparency and active citizenship (USAID, 2014). 
Table 1.1. The average of legal environmental dimension of NPOs in Albania and some Southern European countries, 1997-2014.

\begin{tabular}{|c|c|c|c|c|c|c|c|c|c|c|c|c|c|c|c|c|c|c|}
\hline Years & 옹 & 各 & ஓ্: & চ্ণ & চ্ণ & ర్ స్ & ర్రి & ষ্ণ & 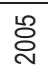 & ষ্ণ & চ্ণি & 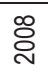 & 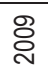 & 응 & $\underset{\sim}{\tilde{N}}$ & $\stackrel{\sim}{\sim}$ & $\stackrel{m}{\grave{N}}$ & $\stackrel{\nabla}{\sim}$ \\
\hline Albania & 4.0 & 4.0 & 4.0 & 4.0 & 4.0 & 3.6 & 3.5 & 3.4 & 3.6 & 3.6 & 3.6 & 3.7 & 3.8 & 3.8 & 3.9 & 3.9 & 3.9 & 3.9 \\
\hline Average & 4.5 & 4.4 & 4.3 & 3.7 & 3.3 & 3.3 & 3.3 & 3.3 & 3.3 & 3.3 & 3.3 & 3.4 & 3.4 & 3.3 & 3.4 & 3.4 & 3.4 & 3.4 \\
\hline
\end{tabular}

Sources: USAID(2014).

In the study conducted by USAID in 2014, the average of legal environmental dimension for countries in Southern European such as: Albania, Bosnia, Bulgaria, Croatia, Kosovo, Macedonia, Montenegro, Romania and Serbia, are presented in table 1.1 (the average results of legal environmental dimension for the years 1997 to 2014, for non-profit sector in Albania and in Southern Europe). The Index of sustainability of NPO, for legal environmental dimension is assessed on a scale of 7-seven point, where the number 7- seven shows extremely low level of development, while a number 1 - indicates a non-profit sectors is developed (USAID, 2014):

A higher level of sustainability and development corresponds between the score 1 - one and 3 - three.

A level of development, the result corresponds between 3.1 - three point one and 5 - five.

A low level of advancement, the result corresponds between 5.1 - five point one and 7 - seven.

Legal environment for NPO-s in Albania, recognizes a strong improvement during the year 2004, to begin to worse for the following years until 2014. Despite these results still needs further improvement of the legal environment for NPOs in Albania. Compared with NPOs in southern Europe the legal environment has been better in Albania until 1999. From year 2000 and on, the non-profit sector in Southern Europe is better than in Albania.

\section{Research Method}

The purpose of this research is to show the historical and legal development of nonprofit sector in Albania. The reason for historical treatment in this paper, is conducted in order to see the beginnings and development until our day of philanthropic activities of non-profit organizations in Albania. It is also explored the legal aspect of nonprofit sector in Albania. A case study was also developed about the historical development, legal and managerial aspect of Red Cross Albania. Red Cross Albania is one of the oldest nonprofit organization in Albania.

According to Merriam (1988) a case study is a format in which the researcher explores a single entity or phenomenon ("the case") bounded by time and activity (a program, event, process, institution, or social group) and collects detailed information by using a variety of data collection procedures during a sustained period of time.

The application of qualitative research consisted of in-depth interviews with managers of nonprofit organization "Red Cross Albania". In addition, a review of their historical material, press releases, and other promotional materials was examined for content and messages. Senior management was targeted for interviews since they are responsible for the vision and mission of the organization.

The site location for this study was primarily located at the office of "Red Cross Albania" organization in Tirana. An in-depth interview technique was used, which consisted of unstructured, open - ended questions to solicit an understanding of how the organization perceives itself.

The secondary data were also used in this study which was achieved through an extensive literature review on historical development and legal aspects of nonprofit sector in Albania, but what was achieved through this data was only theoretical.

\section{Case Study - Red Cross Albania}

The Red Cross is a nonprofit organization founded in 1859, by Henry Dunant. It is one of the most popular organization in the world in support of victims of natural disasters and other emergencies. It is estimated to have more than half a million volunteers and 35,000 employees operating in 188 countries worldwide (Albanian Red Cross, 2014).

The first agreement between the states was conducted in 1864, which constituted the treaty that outline the rules for which were written by Mr. Dunant, became known under the name of the First Geneva Convention. Today there are a host of agreements in this area that form what is known as international humanitarian rights. For this reason it was 
decided to use the same identification mark from all countries and in all conflicts: a red cross on a white field. From this emblem later took the name the aid organization, which were called the Red Cross organization. The flow of history made the countries of the Arab world and the Muslim religion to replace the Red Cross with another emblem: a red crescent on a white field. These two symbols have today the same purpose and the same value (Albanian Red Cross, 2014). Since the act conducted in 1859 on the battlefield of Solforino - help the suffering human regardless of nationality - the work of the international movement of the Red Cross and Red Crescent has developed over the years including numerous activities, often created by long experience, sometimes hurried improvised on various grounds, but always based on some of humanitarian values. These values are expressed concisely in seven fundamental principles of the movement, which are the basis of the activities of the associations of the Red Cross and Red Crescent at any time. These principles are: Humanity, Impartiality, Neutrality, Independence, Voluntary Service, Unity and Universality (Albanian Red Cross, 2014).

Red Cross Albania is the oldest humanitarian association in Albania and it is the only association of the Red Cross in the entire territory of Albania (Statute of the Red Cross Albania - Article 3, 2007). It was established on 4 October 1921 and is officially recognized by the International Committee of Red Cross in 1923. Since this year is a member of the Federation of Red Cross and Red Crescent, being so a 38- association established by then. In this way the Albanian Red Cross is part of the International Movement of Red Cross and Red Crescent. Albanian Red Cross has the right to use the emblem in accordance with the Geneva Conventions of 10 August 1949 and additional Protocols of 10 June 1977 (Parliament Of The Republic Of Albania, Article 5 - the law Nr.7864, 1994).

During the years 1969-1990 the Albanian Red Cross has not worked as a result of the communist regime that existed in Albania. Year 1991- resumes again the activity as a new association, creating its full legal basis and an organizational structure (Albanian Red Cross, 2014).

The national character of the Red Cross Albania is that the country has a single organization of the Red Cross, which extended all the activities in the country and respect the fundamental principles of the International Movement, assisting the public authorities in military health, in accordance with the Geneva Conventions, also in other humanitarian activities. Red Cross Albania counts 39 branches spread all over Albania in cities such as Tirana, Shkodra, etc. But the international character of the Albanian Red Cross is that it is an active part of the International Movement of Red Cross and this is because the Albanian Red Cross is recognized by the International Committee of the Red Cross (Albanian Red Cross, 2012).

The vision of Red Cross Albania is:

"to be a developed humanitarian association, that works to improve the lives and dignity of people in need, in accordance with the Fundamental Principles of the International Red Cross and Red Crescent." (Albanian Red Cross , 2014)

The mission of Red Cross Albania is:

"To helps vulnerable people by mobilizing the power of humanity of society through its humanitarian activities." (Statute of the Red Cross Albania- Article 7, 2007)

The organization structure of Red Cross Albania consists of central bodies and branches (Statute of the Red Cross Albania - Article 7, 2007). Central authorities of Red Cross Albania are: General Assembly and Council of Directors. The bodies of the branches are: Meeting of the members in the branch and the Council of the branch.

Red Cross Albania operates according to the statute that is established by the his General Assembly (Parliament Of The Republic Of Albania, Article 4 - the law Nr.7864, 1994). Red Cross Albania is a legal person and he can exercise an economic activity to provide financial resources to cope with its humanitarian activities (Parliament Of The Republic Of Albania, Article 6 - the law Nr.7864, 1994). Also Council of Ministers can support humanitarian activities of the Red Cross with budgetary funds (Parliament Of The Republic Of Albania, Article 7 - the law Nr.7864, 1994). Red Cross Albania accepts unlimited contributions from individuals in any form, physical and legal persons or foreign Albanians (Parliament Of The Republic Of Albania, Article 8 - the law Nr.7864, 1994). Red Cross Albania is exempt from paying any tax or fee (Parliament Of The Republic Of Albania, Article 9 - the law Nr.7864, 1994).

\section{Conclusions}

The main conclusions of this paper are:

o The non-profit sector is very important for the whole scheme of a country life. 
- In the global level, during the last 30 years had a huge increase in the number of non-profit organizations and this in response to changes in environmental, social and economic conditions.

- The first traces of philanthropy among Albanians have early roots and lie since the period of the Middle Ages.

- The history of development of NPO in Albania is divided in three periods. The first period conclude with the end of Second World War, the second phase covered the period of the communist regime during the years 1945 to 1990 , meanwhile the third period include that after the year 1990 up to our days.

- Cooperation with government at any level is considered normal and necessary by NPOs.

- Legal environment for NPO-s in Albania, recognizes a strong improvement during the year 2004 , to begin to worse for the following years until 2014.

- The legal environment in Albania in which NPOs operate did not change significantly in 2014. No tangible progress has been achieved with regard to registration procedures, the taxation system, or the operational environment.

- Tax Incentives, do not sufficiently motivate the private sector to sustain activity of NPOs.

- In the absence of foreign donors, it would be a limited number of non-profit organization in Albania, because these donors are the majority of which support them financially.

- Nonprofit organizations in Albania may already performing both the economic activity, and this constitutes a most important changes on new legislation.

- In Albania, all NPO-s conduct the registration process to Tirana Court of First Instance and subsequently registered in the local tax authorities.

- Legal environment for NPOs in Albania, needs further improvement.

- Red Cross Albania is one of the oldest and biggest nonprofit organization in Albania.

\section{Refereneces}

Agaraj, XH (Shehu)., Pjero, E dhe Guga, K., (2012): "Development of Nonprofit-Sector in Albania", AUDOE, Vol 8 (6): 13-25.

Stubbs, R., (1998): "A Recipe for Nonprofit Success: "Managing the Linkages and Key Elements of Successful Organizations", Fund Raising management: $17-20$.

Sergante, A., (2009): "Marketing Mangement for nonprofit organizations": Oxford University Press Inc.

Salamon, L; Sokolowski, W and List, R., (2003): "Volunteering in Cross National Prespective: Evidence from 26 Countrie": The Johns Hopkins Comperative Nonprofit Sector Project: 2001.

Weisbrod, B., (1978): "The Voluntary Independent sector": Lexington Books.

Hoxha, A., (2011): "Një Vështrim Historik mbi Zhvillimin e Filantropisë në Shqipëri": Partnerët Shqipëri.

USAID., (2011): "2010 NGO Sustainability Index for Central and Eastern Europe and Eurasia - 14th Edition": United States Agency for International Development.

USAID., (2013): "2012 NGO Sustainability Index for Central and Eastern Europe and Eurasia - 16th Edition": United States Agency for International Development.

USAID., (2014): "2013 NGO Sustainability Index for Central and Eastern Europe and Eurasia - 16th Edition": United States Agency for International Development.

AQSH., (1936); "Fondi 149, Dosja V-217", Arkivi Qendror i Shtetit të Republikës së Shqipërisë, 1936, fl 2.

IDN dhe CIVICUS., (2010): "Civil Society Index For Albania - In Search of Citizens and Impact': Institute for Democracy and Mediation, Tirana.

Partners Albania., (2013): "Pjesëmarrja E Shoqërisë Civile Dhe Qytetarëve Në Vendimmarrje", Partnerët Shqipëri, Qendra për Ndryshim dhe Manaxhim Konflikti, Tiranë, Shqipëri, 2013.

Partners - Albania., (2002): "Raport Vlerësimi i Nevojave të OJQ-ve": Partnerët - Shqipëri, Qendra për Ndryshim dhe Manaxhim Konflikti.

Picari, B., (2009): "Ndikimi i ndërkombëtarëve nëpërmjet organizatave jofitimprurëse në procesin e zhvillimit". Revistë Shkencore $\mathrm{E}$ Fakultetit Të Shkencave Sociale Polis, Vol 8 (1): 2-10.

Merriam, S.B., (1988). "Case Study Research in Education; A Qualitative Approach": San Francisco: Jossey-Bass.

Red Cross Albania., (2007): "Statuti i Kryqit Të Kuq Shqiptar - neni 3": Kryqi i Kuq Shqiptar: Tiranë.

Red Cross Albania., (2007): "Statuti i Kryqit Të Kuq Shqiptar - neni 7": Kryqi i Kuq Shqiptar: Tiranë.

Red Cross Albania., (1994): "Ligj nr.7864 - Për Kryqin e Kuq Shqiptar": Botim Fletoria Zyrtare e Kuvendit të Shqipërisë.

Hasaj, A and Kruja, D., (June, 2012): "The Marketing Concept: Market Orientation and the Performance of Nonprofit Organizations in Albania". Society Internationalization-Effectivity and Problem, Vol (2): 195-199. 